\title{
Civilisations
}

Revue internationale d'anthropologie et de sciences

humaines

43-2 | 1996

Problèmes africains contemporains

\section{The crisis of democratic consolidation in Zambia}

Julius 0 . Ihonvbere

URL: http://journals.openedition.org/civilisations/1570

DOI: 10.4000/civilisations. 1570

ISSN: 2032-0442

Publisher

Institut de sociologie de l'Université Libre de Bruxelles

\section{Printed version}

Date of publication: 1 April 1996

Number of pages: 83-109

ISBN: 2-87263-160-7

ISSN: 0009-8140

\section{Electronic reference}

Julius O. Ihonvbere, «The crisis of democratic consolidation in Zambia », Civilisations [Online], 43-2 | 1996, Online since 29 June 2009, connection on 30 April 2019. URL : http:// journals.openedition.org/civilisations/1570 ; DOI : 10.4000/civilisations.1570 


\title{
The crisis of democratic consolidation in Zambia
}

\author{
Julius O.IHONVBERE \\ University of Texas, Austin
}

\section{Résumé}

La récente vague démocratique en Afrique qui a défié les dictatures militaires, unipartites et personnelles a été confrontée à d'énormes obstacles. Malgré un soula-gement certain lié à la libération de la société civile de sa suffocation traditionnelle, le développement des nouveaux mouvements et des partis politiques a été freiné par une vision limitée, un asservissement ex-cessif à des programmes économiques et politiques contrôlés par des étrangers, l'opportunisme, l'élitisme, la corruption, la dépendance vis-à-vis de loyautés primordiales, la marginalisation des femmes et des personnes issues de milieux ruraux, ainsi que par l'incapacité de ces nouveaux mouvements et partis politiques à se différencier des régimes discrédités dans le passé. En Zambie, la victoire époustoufflante du Mouvement pour la Démocratie Multiparti (MMD) en 1991 ne s'est pas traduite par une amélioration significative des conditions de vie du peuple. Ayant amplement élargi la sphère politique, le gouvernement MMD demeure toutefois non seulement conservateur, mais également incapable d'établir un ordre véri-tablement transparent, responsable, moral et politique. Le MMD s'est vu confronté à des difficultés dans ses politiques ethnique et régionale et a été affaibli par plusieurs scandales. L'avenir de la démocratie en Zambie 
dépend du degré de consolidation de la libéralisation, de la véritable démocratisation du système politique, de la mobilisation du peuple, de leurs communautés et d'organisations, ainsi que de leur partage du pouvoir, du démantèlement de l'Etat néo-colonial répressif et de la construction d'un Etat national populaire.

The past few years have witnessed a democratic awakening in many parts of Africa. It is one thing for democratic regimes to emerge, quite another for democracy to flourish and endure. The latter can only happen if democratic change is effected and institutions established that actually function as guardians of the democratic process and of the people?

People think that once you have got a democracy, everything is going to be free of charge. The danger is impatience ${ }^{2}$.

The final outcome of these on-going processes of democratic transition in Africa is uncertain at best, and experts' analyses and predictions range from guarded optimism to frank pessimism....Any effort to superimpose a specific narrow formula of democracy could lead to mere formal compliance, such as allowing multipartism without "real democracy ${ }^{3}$."

1 . RASHEED SADIG, "Africa at the Doorstep of the Twenty-First Century: Can Crisis Turn to Opportunity" in Adebayo Adedeji, (ed.), Africa Within the World: Beyond Dispossession and Dependence, London and Ijebu-Ode: Zed Books and ACDESS, 1993, p. 47.

2 . SOGLO NICEPHORE, President of Benin quoted in Jeune Afrique, 1632, 16-22 April 1992.

3. MARTIN GUY, "Preface: Democratic Transition in Africa," Issue: A Journal of Opinion Vol. XXI,(1-2), 1993, pp. 6 and 7. 
The recent wave of democratic openings and struggles in Africa has challenged not just one-party political systems and personal rule, but also military dictatorships, pseudodemocracies, and the general suffocation of civil society. With the on-going changes in the global order and the gradual recomposition of socio-economic and political relations, Africa has not been left out of the political, if not the economic wave. Yet, while the military has civilianized itself in Ghana, lifepresidents have given way to the popular will in Malawi, apartheid has been more or less dismantled in South Africa, and communist governments have crumbled in Benin and Ethiopia, the major challenge confronting these courageous efforts at political renewal has been the consolidation of democracy. Many of the new political parties and prodemocracy movements received financial, ideological, and other logistical support from donors, lenders, Western governments and other foreign agencies. Some did succeed in mobilizing internal opposition in the struggle to challenge dictatorship and authoritarianism. Yet, the ground-swell of support received at the initial stages have not translated into consistent, predictable, or permanent support in the post-election periods ${ }^{4}$. As Denis Venter has noted in the case of Malawi, the "liberation dividend" has not followed the truly political earthquake which saw the defeat of Kamuzu Banda, one of the continents most infamous dictators: "The restoration of aid promised by donors on condition of the successful completion of the democratization process has yet to materialize in any significant way."

To be sure, the political changes in the continent are precipitates of a complex set on internal and external factors and developments. Though in large measure a manifestation of the

\footnotetext{
4 . GOLDSMITH ARTHUR A., "Political Freedom and the Business Climate: Outlook for Development in Newly Democratizing States," Social Science Quarterlv Vol. 75, (1), March 1994, p.115.

5 . VENTER DENIS, "Malawi: the Transition to Multi-Party Politics," in WISEMAN JOHN, (cd.), Democracy and Political Change in Sub-Saharan Africa London: Routledge: 1995, p.180.
} 
continuing struggles against the betrayal of the early years of political independence when the nationalists appropriated the powers and privileges of the departing colonial powers, more recent events have also propelled the calls for political renewal. The delegitimization of the repressive and non-hegemonic neocolonial state; the unbridled corruption and irresponsibility of the dominant classes; the decay of infrastructures and basic services; widespread corruption, mismanagement, and the marginalization of the people from decision-making processes; the suffocation of civil society and the closures of all outlets for independent political expression; the emergence of new political leaders, political movements, and interest groups making open demands for political pluralism; and the unequal distribution of the costs and pains of World Bank and IMF dictated and directed structural adjustment programs. On the external front we can identify the events in Eastern Europe, the end of the cold war and the near irrelevance of old allies of the ideological blocs, the new emphasis on political pluralism, good governance, accountability, and respect for human rights by donors, lenders, and creditors; pressures from debt and debt-servicing obligations; the drastic reductions in foreign aid, foreign investment and foreign interest in most African economies; and impact of the new globalization which required extensive political, social and economic restructuring.

African leaders have responded to these developments in a variety of ways: the national conference, open competitive elections, guided liberalization, opposition to pluralism, attempts to divide the opposition through bribery and/or the registration of scores of opposition parties, co-optation, and intimidation. Irrespective of the adopted strategy, the new political movements have succeeded in compelling military dictators to accept political pluralism (Benin, Babangida's Nigeria, and Ghana); one-party regimes to allow for more parties (Kenya and Zambia); and oneperson life-presidential systems to adopt multiparty political systems (Malawi). The national conference has been more of a Francophone phenomena which has been utilized in Benin, Congo, Mali, Gabon, and Niger. 
Though it is true that "democracy is spreading like bushfire throughout Africa," ${ }^{16}$ at least until recently, the new prodemocracy movements and political parties have tended to exhibit some common traits: corruption, opportunism, the marginalization of women, concentration in specific regions or urban centers, personalization of politics, confusion, fragmentation, excessive ambition and focus on power, and an unabashed acceptance and consumption of conservative, monetarist programs of the IMF and World Bank. The movements and new parties operate and sound very much like the parties of the 1960s, they develop no new arguments and programs beyond a superficial clamor for democracy, they hardly cultivate new constituencies and communities, and without exception, they seek to validate their democratic credentials, not by critically inserting themselves in local communities and organizations, but by courting foreign foundations, agencies, governments, and donors. This is not to discountenance the great risks they have taken in challenging regimes and leaders with long standing reputations for intolerance, brutality, and human rights abuses. The superficial, defensively radical, opportunistic, diversionary, and narrow focus of the organizations, politics, and strategies have eroded their legitimacy, bred confusion, and made it easy for the incumbent governments to penetrate, divide, and out-manoeuver them in the competition for power?

Finally, the process of political liberalization in Africa has, in spite of widespread expectations, failed to bring about fundamental changes. It was expected that the political upheavals and the political rhetoric of the new political leaders would heighten expectations among hitherto exploited, marginalized, oppressed, and intimidated communities and persons. Promises were made about food, water, shelter, health care, better roads,

\footnotetext{
6. MARTIN GUY, "Preface: Democratic Transition in Africa," op. cit., p. 6.

7 See IHONVBERE JULIUS 0, On the Threshold of Another False Start?: A Critical Evaluation of Prodemocracy Movements in Africa, paper presented a the 1lth Annual Mecting of the Council of Nigerian People and Organizations (CONPO), Washington, D.C., September 14-17, 1995.
} 
power supply, good schools, loans to farmers, better wages, inflation control, the termination of crime and prostitution, open governance, accountability, respect for human rights, and the involvement of the people in the political processes and in decision-making. In short, the people were promised a better life. This has not happened in any country. In Nigeria, the process culminated in a military coup in November 1993 bringing to power one of the most insensitive and ruthless military junta in that nation's political history. In Kenya, "political paralysis, high rates of inflation, and insecurity have become the order of the day since the Moi government stole an election in December $1992^{8} . "$ Denis Venter points out that "Malawi has shown that democracy can cure some ills but may worse others." The removal of Banda's despotism has unleashed a corrupt and careless press, "unprecedented urban crime... a generally deteriorating security situation,...marked increase in, especially, crimes of violence," and worsening economic crisis ${ }^{10}$. Finally, Harvey Glickman notes that in spite of democratic openings all over the continent, governments "are still unable to arrest economic decline," and while liberalization has certainly meant "more freedom," it has also meant "more strife" and legitimacy of the new democratic governments. Deepening economic and social crisis, inability to meet the needs of the people, and the general picture of confusion, indecision, and inexperience in many instances have culminated in coups or attempted coups, mass withdrawal of support for new governments, the emergence of scores of opposition parties, harsh media attacks on the governments, and the return of the

8. MAKaU WA MUTUA, "U.S. Foreign Policy Towards Africa," in William Minter, (ed.), U.S. Forei n Policv: An Africa A enda, Washington, D.C.: Africa Policy Information Center, 1995, p. 16.

9 . VENTER DENIS, "Malawi: The Transition to Multi-Party Politics," op. cit., p. 178.

10 . ibid, p. 181.

11. GLICKMAN HARVEY, "Editor's Introduction," Issue: A Journal of Opinion Vol. XXI, (1-2),1993, p.3. 
people to ethnic, regional, religious, and patron-client bases of survival.

It is the inability of the new regimes to contain political fragmentation, genuinely open up civil society, present a viable agenda for economic and social recovery, and mobilize the people for self-reliance that has generated the new pessimism about political liberalization in Africa. Adebayo Adedeji captures well this new frustration with the democratization process when he notes that "this process has been largely aborted and subverted, the very subversion in some cases master-minded by the very leaders who had proclaimed their commitment to the realization of democracy. Indeed, the past...years have witnessed oscillations between tumult and paralysis, and have shown more clearly than ever before the deep-rooted and systemic weaknesses of current leadership in Africa ${ }^{12}$." In a more recent address Adedeji noted that "the idea of a second liberalization in Africa has gone away with the wind, at least temporarily. Even the most timid attempts at democratization have often failed due to self-centeredness of African leaders and their lack of vision ${ }^{13}$." It is becoming clear, as a respondent put it in Lusaka, that "the defeat of dictators is much easier than replacing the dictators. Building true democracy is more of a challenge. So far, we are not having much luck in Zambia because of overwhelming problems ${ }^{14}$." How has Zambia fared with its new liberalization since the 1991 elections which saw the routing of the 27-year government of Kenneth Kaunda and the United National Independence Party (UNIP)? Has the emergence of the Frederick Chiluba-led Movement for MultiParty Democracy (MMD) led to the genuine movement from

12. ADEDEJI ADEBAYO, "The Case for Remaking Africa," in RIMMER DOUGLAS, (ed.), Action in Africa London: James Currey and Heinemann, 1993, p. 44.

13. ADEDEJI ADEBAYO, Keynote Address at the conference on "An African Agenda for Economic and Social Transformation in the New Global Environment, Lincoln University, November 17-18, 1994.

14. Interview with an MMD Member of Parliament, Hon. Samuel Miyanda, Lusaka, June 1993. 
democracy to democratization, the mobilization of the people, and the consolidation of the new democratic enterprise?

\section{The Crisis of Democratic Consolidation in Africa}

It is important to distinguish between political liberalization and democratization especially in the African context ${ }^{15}$. Liberalization is quite possible without democratization. The former simply involves the establishment of a more open political order, the dismantling of the institutions and constraints of dictatorship, and the reduction, not necessarily elimination, of controls, human rights abuses, and restrictions of personal and collective liberties ${ }^{16}$. The transition from political liberalization to democratization is often mediated by a range of problems: the legacy of the defeated dictator along with inherited institutions and structures; contending constituencies; primordial loyalties; factions within the military; economic deterioration and decay; institutional inefficiency and ineffectiveness' gross inequality in power, opportunities, amenities, and income; alienation from the state arising from earlier conditions of human rights abuses and marginalization; and the need to meet overblown expectations. What has been going on in virtually all African states, is political liberalization, evidenced in a concentration on procedural

15. See LEMARCHAND RENE, "African Transitions to Democracy: An Interim (and Mostly Pessimistic) Assessment," Africa Insight Vol. 22, (3) 1992; HEALEY J AND ROBINSON M., "Democracy. Governance and Economic" Policv: Sub-Saharan Africa in Comparative Perspective, London: Overseas Development Institute, 1992; and PINKNEY ROBERT, Democracvyin the Third World, Boulder: Lynne Reinner, 1994.

16. According to HEALEY and ROBINSON, political liberalization involves a situation "in which the fear of repression is relaxed and there are constitutional guarantees of a range of political freedoms (especially the recognition of the right of opposition groupings to function and to express dissent) in which there is greater independence for legislative assemblies where they still exist, and freedom of the press." See HEALEY J AND ROBINSON M., "Democracy. Governance and Economic Policy" op. cit., p. 151. 
democracy. This process tends to focus on the creation of multiparties, constitutional engineering, campaigns, the constitutional guarantee of basic freedoms, and periodic elections. While these are certainly important, unless the process goes significantly beyond elections, it is quite easy to domesticate or contain the process, or to terminate it as was the case in Nigeria. To be sure, even the mere liberalization of the political landscape allows for the establishment and operation of opposition parties, the articulation of alternative political programs, the training of new leaders, and provides opportunities for deepening local politics beyond established levels. However, if it does not build a genuinely democratization project into the process, initial victories by popular forces can end up in disaster, further alienating the people, and generating what Samuel Huntington rightly calls "authoritarian nostalgia": where the bad old days suddenly look so rosy and much better! ${ }^{17}$ Huntington points out that "authoritarian nostalgia could conceivably pave the way for the "slow death" of a democratic regime, with the military or other authoritarian forces resuming power ${ }^{18}$." It is in this context that we can better appreciate the rising popularity of Kenneth Kaunda in Zambia and the way in which this development has scared the Chiluba government into all sorts of desperate political moves (see below).

Democratization involves the steady and systematic empowerment of the people, their organization, and communities in a direction which empowers them to dictate, influence, and determine the content and context of politics. Democratization allows the people to incorporate their interests in the institutions and structures of the state, and this makes it possible for public policy to reflect the interests and aspirations of the people. Finally, democratization makes it possible for politics to reflect the issues close to the people: gender equality, human rights,

17. HUNTINGTON SAMUEL P., The Third Wave: Democratization in the Late Twentieth Centurvy Norman: Oklahoma University Press 1991) p. 262.

18 . ibid 
environmental protection, basic needs, participation in decisionmaking, accountability of the leadership, expansion of democratic spaces, and the non-appropriation of the voices of the people. An agenda for democratization makes it possible for democracy to be consolidated largely because it develops and nurtures an environment for collective contribution to projects, collective acknowledgment of problems, and collective acceptance of mistakes. The nature and politics of the contemporary political parties and movements have provided ample opportunities for skepticism about the future of democracy, much less, the consolidation of democracy in Africa:

...it seems highly likely that third wave democratic regimes will not handle these problems effectively and that they will, in all probability, be no more or less successful in doing this than their authoritarian predecessors. Insurgencies, inflation, poverty, debt, inequality, and/or bloated bureaucracies will continue more or less as they have in previous decades ${ }^{19}$.

In Zambia, the liberalization agenda, and the new democratic government of the MMD has been tasked by the very problems outlined above. As a Movement, government, and political party, the MMD has had to contend with problems of legitimacy, the intransigence of the defeated authoritarian regime, strong opposition from UNIP stalwarts and leaders, worsening economic crisis, scores of strikes and protests by workers, students and peasants; ethnic and communal conflicts, regional challenges to central authority, severe socio-economic inequality, and the constraining effects of debt and debt-servicing obligations. Zambia is, today, paying very dearly for almost three decades of despotism, corruption, waste, mismanagement,

19 . ibid, p. 255. 
sectoral distortion, and ideological experimentation ${ }^{20}$. According to Jowie Mwiinga, "Increasingly, Zambians are beginning to feel they have been short-changed by the Chiluba establishment. Most are now beginning to regard the Kaunda years with nostalgia ${ }^{21}$." It will be an exaggeration to contend that life has improved for the average Zambian in spite of the promises and efforts of the MMD. As Lance Morrow noted recently, "Zambia has become one of the poorest nations anywhere, with one of the world's highest per capita foreign debts- nearly $\$ 1000$ for each of its 8 million people; average annual income per person is less than $\$ 290 \ldots . .22$ These developments and conditions certainly do not augur well for the survival of liberal democratic institutions much less genuine democratization $^{23}$.

\section{The 1991 General Elections in Zambia}

The UNIP and Kenneth Kaunda was certain that they would win the 1991 elections. In spite of the massive following which the MMD enjoyed, and in spite of the international goodwill in its favor, the UNIP was certain that it could successfully rely on rural interests and the power of incumbency to win the elections. The process leading to the 1991 general elections was rough and full of conflicting and complex developments, accusations and counter-accusations, efforts to manipulate the state and its resources, appeals to the masses for

\footnotetext{
20. See ibid, pp. 252-255.

21. MWIINGA JOWIE, "Chill for Chiluba," Africa Report, March-April, 1994, p. 60 .

22 . ibid.

23. See IHONVBERE JULIUS 0. Economic Crisis. Democratization and Civil Society in Zambia Forthcoming Lawrenceville, NJ: Africa World Press, 1996.
} 
support, and some violence ${ }^{24}$. Both parties relied on patronage politics by giving out gifts, making outlandish promises, courting particular constituencies, and trying to exploit existing frustrations and fears. The UNIP and the MMD also relied on the manipulation of the pains and expectations of the Zambian people. While the UNIP relied on traditional institutions and hoped to win the support of rural dwellers, the MMD relied on support from the urban areas and on reaping gains arising from the low popularity of Kaunda and UNIP as a result of economic problems. The UNIP was shocked to discover that rural dwellers were already feeling the pains of the party's failed economic programs. The MMD relied on the extensive and effective networks of the Zambian Congress of Trade Unions (ZCTU) which Chiluba, the MMD flag bearer had led for almost two decades. It also relied on the churches across the nation to mobilize its supporters. Though the UNIP tried to exploit the power of incumbency and its control over the media, it could not convince the majority of Zambians that it had any new ideas for dealing with the mounting economic problems and reviving the economy. At the October elections, the UNIP was roundly defeated, winning only 25 of the 150 seats in parliament, and losing the presidency to the $\mathrm{MMD}^{25}$. Zambians were so fed up with the UNIP and Kaunda that very few took notice of the MMD's promise to stick more stringently to IMF and World Bank adjustment programs. Very few paid attention to the fact that the leading cadres of the MMD were actually persons who had served Kaunda very well in the UNIP and had been dismissed for one offence or the other. Most Zambians took little notice of the political and public record of the MMD leadership and bothered to discuss what impact this would have on the party once it came to power. No one bothered to ask how the MMD

24. JOSEPH RICHARD, "Zambia: A Model for Democratic Change," Current Historv, May 1992) p. 200. See also his "Africa: Rebirth of Political Freedom," Journal of Democracv Vol. 2, (4), Fall 1991.

25. See BRATTON MICHAEL, "Economic Crisis and Political Realignment in Zambia," in WIDNER JENNIFER, (ed.), Economic Change and Political Liberalization in Sub-Saharan Africa, Baltimore: The Johns Hopkins University Press, 1994. 
planned to covert itself from a Movement (made up of differing, even conflicting interests) into a government in post-UNIP Zambia. Finally, the MMD never placed before the Zambian people how it planned to challenge, recompose, and redefine the philosophical basis of politics and power in Zambia, as well as how it would wean the institutions and structures of state and society away from the authoritarian legacies of the UNIP.

\section{The MMD in Power 1991-1995: Still No Recovery in Sight}

When the MMD came to power in 1991, its victory was greeted by analysts and Western governments as a shining example to other African states. The smooth transition from Kaunda's authoritarian one-party system to a liberal multiparty political arrangement was seen as an encouraging sign that democracy would not only thrive in Zambia, but also that it would facilitate economic growth and recovery. Chiluba's trade union background, the broad consensus of interests which the MMD represented, and its open commitment to structural adjustment were seen as very positive factors which would support the democratic enterprise. Furthermore, its comfortable majority in Parliament was seen as advantageous in that it would remove stalemate, delays, and unnecessary disagreements over programs required to promote economic recovery and the consolidation of democracy. Of course, the massive support which the MMD had enjoyed from foreign interests also gave the impression that foreign aid would flow into the country, investors would be reattracted, debt concessions would reduce debt-servicing obligations, and the new democratic government would distinguish itself through its ability to improve the terrible living conditions of the poor majority. For the teeming supporters of the MMD, the "Hour" for their liberation from poverty, intimidation, and marginalization had truly come.

Unfortunately, things have not worked out quite well for the MMD in Zambia. Even the government agrees that it has failed 
to live up to expectations though it frequently blames these failures on the UNIP legacy, the global environment, lack of foreign aid and investments, and the low spirituality of Zambians. The National Commission for Development Planning noted in its 1992 report that the "prospects for employment in 1993 are not very promising due to envisaged loss of jobs because of factors such as: privatization; retrenchment in the public sector; continued credit squeeze which is likely to restrict investments; and measures to control inflation are likely to cause a contraction in the economy and hence inhibit expansion in employment ${ }^{26}$. "Its 1993 and 1994 reports were no different. In virtually every sector, the results of the MMD's reform programs were disappointing. Emmanuel Kasonde, as finance minister made it clear to Parliament in his 1993 budget address that in spite of the NERP and support from donors and lenders, "some major challenges remain. Our main problem is inflation. Unless we drastically reduce the rate of inflation, the economy will not stabilise, confidence will not return, investment will remain depressed, and we will fail in our attempt to regenerate economic growth $^{27}$."

For 1993, the primary objective of government recovery programs focused on tighter fiscal policies; reduction in domestic borrowing by government and the parastatals; bringing inflation down to 10 percent; abolishing supplementary appropriations to government ministries; repaying much of government outstanding debt to the banking system; freeing up resources for private sector expansion, and running the government on a cash basis. The Bank of Zambia was instructed to "deny any government transaction unless there are adequate funds in the appropriate accounts $^{28}$." An extensive tax review, administration, evaluation, and collection system was introduced; a Special Fund was created

\footnotetext{
26 . Republic of Zambia, Economic Report 1992, op. cit., p. 21.

27 . KASONDE E. G., Budget Address by Minister of Finance to the National Assemblvyon 29th Januarv 1993, Lusaka: Government Printer, 1993, p. 9.

28 . ibid, p. 19.
} 
for revenues from the privatization of government companies; K2 billion was earmarked for rehabilitating Zambia's terrible road network; tax relief for the handicapped and low-wage earners was introduced and along with other tax measures the government expected to raise K15 billion in 1993. Proposed expenditure for 1993 was put at K231.9 billion: K197.1 billion was designated as non-drought expenditure, K34.8 billion as drought related. Of the K231.9 billion proposed expenditure, K19.8 billion was expected from the sale of donated maize and K212.1 billion from other domestic sources. Noting that "tax incentives are not the foremost considerations among serious investors," the MMD government contended that investors would consider "favourable macroeconomic policies, political stability, security, the availability of resources and markets, and liberal provisions for the repatriation of profits." As a measure of the degree of openness of the economy and in addition to the "package of tax measures" which should "attract investors and stimulate investment," the MMD government announced that it "will allow the repatriation of 100 percent of after tax profits, with no restrictions, and no bureaucratic screening ${ }^{29}$." This new posture in itself generated heated debates on the possible recolonization of the Zambian economy. However, except for UNIP members (and until the recent emergence of several opposition parties), it was not politically wise to oppose the MMD publicly at that time.

As of the middle of 1995, the government had not recorded significant successes in its recovery program. In May 1995, it faced another severe drought. Like in the 1992 experience, the government was ready and made plans well beyond the traditional reliance on foreign sources to assist affected communities. As part of its privatization program, the MMD government liquidated Zambia Airways and sent hundreds of workers into unemployment thus swelling the ranks of the 70,000 public employees already retrenched. Twenty more state companies are listed for liquidation before the end of 1995. This is of course, a very painful choice for a government that derived 
its legitimacy and support from popular constituencies. Yet, the size of the civil service needed to be cut, inefficient parastatals like the Kabwe Mines needed to be gotten rid of, and there was the need to strengthen the productive capacities of Zambians by making them rely less on state subsidy.

Unfortunately, rather than bring Zambians together, the privatization program of the government seems to be alienating the people, eroding the government's legitimacy, and creating pockets of opposition. Those who have been laid off frequently blame the government. As well, many workers have not benefitted from the privatization program in spite of efforts to broaden public participation. The 15 firms sold thus far went to "well established businessmen and multinationals who could afford to bid for them ${ }^{30}$." For instance, the 54 million shares sold during the privatization of the Chilanga Cement company was pegged at K65,000 "minimum investment" and the majority of Zambians could not afford such an amount ${ }^{31}$. The level of indignation had reached worrisome proportions and criticism against the government could be heard all over Lusaka and other major cities.

Contrary to its campaign promise, infrastructures are still in very bad shape. The MMD government has not been able to rehabilitate most roads, public buildings, and services. Though it does lack the foreign exchange, the corruption within the government makes most Zambians -to believe that "the government is just like the previous one. It cares for only the rich $^{32}$." Inflation which was at 200 percent in 1991 had practically destroyed the social fabric of the nation though it has been brought down to 30 percent. This feat, however, is not reflected

30. MWIINGA JOWIE, Zambia Economy: Stock Exchange Finds its Feet, Inter Press Service, Peace Net, May 10, 1995.

31 . ibid

32. Interview with MWANSA MARK, Mamba Collieries Guest House, Lusaka, June 1993. 
in prices or in the real value of wages and salaries. Though the MMD continues to reiterate its full commitment to governmental transparency and to structural adjustment, the problem of corruption within the government has continued to erode the government's credibility and create dangerous political divisions. This problem is so endemic that it has divided the party, led to the dismissal or resignation of ministers and some founding members of the MMD, forced the donor community to withhold foreign aid, and tainted the good intentions of the government. Scandals in the cabinet, inefficiency, contradictory pronouncements, and sycophancy a la Kaunda have come to dominate MMD politics in Zambia. Ministers like Roger Chongwe (Legal Affairs) have used their positions to illegally acquire acres of land. Ronald Penza, Derrick Chitala, and Matthew Ngulube have also "grabbed land" illegally ${ }^{33}$. The former vice-president, Levi Mwanawasa resigned in mid-1994 in the heat of accusations about abuse of office and power. Former foreign affairs minister, Vernon Mwaanga who had been arrested in 1984 at Frankfurt International Airport on drug trafficking charges continued to be accused of running a drug ring. His son, Maliko was arrested recently after he was found with high grade cocaine worth 70,000 pounds sterling ${ }^{34}$. Sikota Wina, another founding member of the MMD, as well as Princess Nakatindi Wina had to resign from the government following several accusations of drug trafficking. The list of MMD ministers and prominent officials who are well known for abuse of office, drug trafficking, corruption, indiscipline, and incompetence is quite long. In spite of Chiluba's personal "born again" claims, Zambians see him as ineffective and unable to control his ministers, who obviously do not share his visions of a new Zambia ${ }^{35}$. These acts of corruption have opened up the MMD to very bitter and critical attacks from the opposition parties and

\footnotetext{
33. See MWIINGA JOWIE, Zambia-Politics: Land Grabbers on Rampage, InterPress Service, Peace Net, May 10, 1995.

34

Service, Peace Net. May 18, 1995.

35 ibid
} 
the public; distracted the government from its goals of adjustment and openness; and constrained the ability of the government to call on Zambians to make sacrifices and accept the pains of adjustment. As well, corruption has led to waste, bureaucratic inertia, the privatization of public positions, the development of unproductive patron-client networks within and outside the government, and the erosion of donor and lender support. Pervasive corruption has also promoted widespread skepticism, even among earlier supporters of the MMD about the MMD's ability to sustain democracy and the reform programs. Democracy in Zambia has not reduced corruption, if anything, it has made the situation worse ${ }^{36}$.

Plural democracy in Zambia has not brought ethnic groups together. It will be recalled that the "original leadership of MMD was dominated by people from one part of the country: Lozis from Western Province ${ }^{37}$." Of course, as the membership grew and political elites defected from the UNIP to join the MMD, its diversified its ethnic composition. Yet, regions and major ethnic groups see the Bembas as dominating the government and unduly diverting resources to the North East. Loud complaints of marginalization and discrimination are heard from the Southern province which had supported the MMD. The Eastern province, Kaunda's base has also complained of being punished for supporting and remaining loyal to UNIP. UNIP's twenty five seats in parliament came from the province. Ethnic and regional identities and loyalties have severely divided Zambian politicians and politics. Today, none of the political parties can strictly be regarded as national in character. The UNIP retains its Eastern base. The MMD remains strong in Lulapula and the Northern Province. The new party, Zambia Democratic Congress (ZADECO) is becoming very popular in the North, and the National Party (NP) is strongest in the West. As Elias

36. See LORCH DONATELLA, "In Zambia, a Legacy of Graft and a Drug Scandal Taint Democratic Reforms," New York Times (January 30, 1994).

37 . KEES VAN DONGE JAN, "Zambia: Kaunda and Chiluba," in WISEMAN JOHN, (ed.), Democracy and Political Chan e in Sub-Saharan Africa, op. cit., p. 199. 
Nyakutemba has rightly noted, "Flourishing regional politics are part of Chiluba's dilemma and he has still put forward no plan for regional autonomy despite the overwhelming recommendations of the Mwanakatwe constitutional review commission ${ }^{38}$." Left unresolved, in the context of failed social and economic programs, Zambians will dissolve into their respective ethnic and regional enclaves with very far-reaching implications for stability, governance, and nation-building.

The MMD has steadily created a platform for religious tensions and conflicts in Zambia. Conflicts between the state and religious interests are not necessarily new given the experiences with Leshina and Watchtower ${ }^{39}$. The MMD Manifesto declared the country a "Christian country which is tolerant of other religions." Though it also declares a commitment to "freedom of thought, conscience, belief and proclamation of faith," by placing one religion above others which are merely to be "tolerated," party seems to be encouraging religious divisions. Chiluba's born again religious positions seems to have emboldened the Christians who now openly make disparaging remarks about other religions. Not only are television programs dominated by religious programs from abroad, but even public functions are full of religious activities. Religious sycophancy" has become part of Zambian politics as most ministers or politicians, as well as contractors have become "born again" Christians! The regions are at war within and between themselves. By refusing to take action against corrupt ministers and politicians, by appointing so many individuals with records of corruption into his cabinet, and by

\footnotetext{
38. NYAKUTEMBE ELIAS, "Zambia: Chiluba's Challenge," New African (November 1995).

39 . See ROBERTS A. D. "The Lumpa Church of Alice Leshina," in ROTBERG R. and MAZRUI A.A., (eds.), Protest and Power in Black Africa New York: Oxford University Press, 1970 and LUNGU G.F., "The Church, Labour and the Press in Zambia: The Role of Critical Observers in a One-Party State," African Affairs (85) (1986).

40. "Movement for Multi-Party Democracy," Manifesto Lusaka: MMD Campaign Committee, n.d, p. 10.
} 
taking very malicious action against those who oppose him, many see Chiluba's born again credentials as questionable. More importantly, this public perception erodes the credibility of the leader, the government, and the party.

Party indiscipline has also become a major problem. The high point of this is evidenced in the conflicts between the central MMD government and regional governors who simply refuse to toe party lines, take orders from the center, and reconcile differences with other levels of authority. In the Northern and Northwestern provinces, as well as in the Copperbelt, acts of insubordination, disrespect for party rules and decisions, and power struggles between MMD stalwarts have at various times played into the hands of the opposition and weakened the party. While these struggles and conflicts often showed that the MMD was yet to see itself as a political party (rather than a movement), they have made it possible for alienated party members to transfer their support to the opposition. Over 34 opposition parties and movements have emerged to challenge the MMD. Many of these are led by former leading members, cabinet ministers, and even founding members of the MMD. Derrick Chitala former state house deputy minister and Dean Mungoba, former deputy development minister formed ZADECO after they were dismissed by Chiluba. The Caucus for National Unity (CNU) was formed by some founding members of the MMD. When Chiluba sacked Emmanuel Kasonde, Arthur Wina, and Humphrey Mulemba as ministers in April 1993, they formed the NP. They were promptly joined by thirteen other parliamentarians like Akashambwata Lewanika and his sister, Inonge Lewanika. Though none of the opposition parties has the clout and resources as well as international visibility of the MMD, their mere existence removes a cadre of leaders from the party. Their criticisms erode the legitimacy of the party and its leader. They have succeeded in recent by-elections in humiliating the MMD, even in its northern stronghold. A major coalition of these opposition parties, increasing scandals within the government, and deteriorating socio-economic conditions could lead to major upsets and a drastic reconstruction of political alignments and realignments in 
Zambia during and after the 1996 elections. For what ever it is worth, this possibility has frightened the MMD and forced Chiluba to become more intolerant of opposition.

The re-emergence of Kenneth Kaunda on the Zambian political scene, the revitalization of UNIP, and the growing influence of some opposition parties, while reflective of the new openness and freedoms in Zambia, is also sowing the seeds for crisis, instability, even disintegration. Chiluba has reacted to Kaunda's growing influence with panic. He has amended the constitution to redefine the qualifications for contesting for the presidency to include a requirement that both parents must be Zambian $s^{41}$. Clearly aimed at Kenneth Kaunda whose parents were Malawians, it has been received with a lot of opposition and unfavorable reaction from within and outside Zambia. Kaunda fought for Zambia's independence and ruled the country for 27 years. To now amend the constitution on the eve of the 1996 elections and only after Kaunda announced his interest in the presidency, and in the light of UNIP victories in by-elections in Mbala, Mpulungu and Mkushi where MMD candidates were defeated, has been seem as nothing short of victimization. To further humiliate Kaunda, Chiluba threw open to public view Yugoslav-constructed security tunnels under the state house in Lusaka. Chiluba argued that the tunnels were used by Kaunda to torture political opponents, though he has so far "failed to prove that torture did take place...." Ka Kaunda argued that the tunnels and bunkers "were gifts from friendly nations to "protect

\footnotetext{
41. Zambia: Chiluba Defends Requirement for President, London: BBC World Service in English, 27 September, 1995. The Government White Paper also stipulated that "no person who has been elected president twice should be eligible to stand again." Sce Kaunda, Minister Respond, London: BBC World Service in English, 27 September, 1995. Legal Affairs Minister, Remmy Mushota has however denied that this was mainly directed at Kaunda. Following statements by Home Affairs minister, Chitalu Sampa that Kaunda would be arrested and deported to Malawi, the government quickly stepped in to contain a situation which had generated tension and led to riots at the University of Zambia when it announced that the minister's statement had no official support.
}

42

. NYAKUTEMBA ELIAS, "Chiluba's Challenge," op. cit. 
liberation leaders and the presidency from South African aggression. "Among those who used the tunnels were Nelson Mandela and Sam Nujoma of Namibia ${ }^{43}$ " Rather than attract sympathy, Chiluba has been widely criticized for exposing Zambian state security to the entire world. As well, he is being accused of gross human rights abuses, authoritarianism, opportunism, tribalism, and lack of capacity to control his ministers. In fact, within the MMD, Chiluba has shown extreme hostility and intolerance to those who contemplate, talk less, articulate the idea of opposing him as presidential candidate in 1996. In fact, Dean Mung'omba who announced such an intention in early 1995 because "Chiluba's government had failed to meet the needs of the poor" and had mismanaged the economic reform program while neglecting agriculture and the rural areas, was promptly relieved of his position first as deputy finance minister, and later as MMD deputy treasurer ${ }^{44}$.

Such repressive and intolerant tendencies work directly against democratic consolidation. As well, such panicky measures simply buy sympathy for the opposition, and has been directly responsible for the increasing support which Kaunda is enjoying. More importantly, it gives the impression that the government is unable to build legitimacy, mobilize the people behind an agenda, and that the people can be manipulated and/or convinced to support an alternative political platform. This perception is exactly what convinced certain elements within UNIP, led by Kaunda's son, Wezi Kaunda, to initiate the controversial "Zero Option" in 1993 as a strategy to oust the Chiluba government from power through extra-legal means ${ }^{45}$. This episode forced Chiluba to, through the MMD-dominated parliament, impose a state of emergency, arrest numerous UNIP leaders and activists, and

\footnotetext{
43 , ibid

44 . Zambian Said Intimidated for Challenging Chiluba," Reuters, 19 May 1995.

45 . For details, see IHONVBERE JULIUS 0., "The 'Zero Option' Controversy in Zambia: Western Double Standards vis a vis Safeguarding Security?" Afrika Spectrum (30) 1995.
} 
charge them to court. This did not go down well with the international community, and Zambians who had suffered under almost Kaunda's two-decade-plus state of emergency. But it did show the fragility of Zambian democracy and the declining popularity of the incumbent government ${ }^{46}$.

Finally, democratic consolidation is not possible with regimes or governments without a strong, reliable, and active constituency. Chiluba rode to power on the back of the Zambian labor movement which he had led until he was elected president in 1991. However, the failure of the MMD's reform program and the lack of improvement in the lives of non-bourgeois forces, have culminated in strikes, riots, and demonstrations by peasants, workers, and students. As Nyakutemba rightly notes, the main problems of Chiluba "remain poverty, high taxes, soaring unemployment and continually falling living standards. There is also the failure of medical and educational care and corruption in the cabinet ${ }^{47}$." This is the basis of alienation from the MMD and the state, increasing support for the opposition, especially UNIP, the NP and ZADECO, and frequent confrontations between the state and the forces of civil society. The ZCTU which he headed for almost two decades is openly opposed to his structural adjustment, especially his privatization program. Teachers have organized strikes against the government as have taxi drivers, local authority workers, and civil servants. Workers located in MMD strongholds in the major cities of Kitwe, Lusaka, Solwezi, Kasama, the Copperbelt, and Kabwe have organized strikes against the government. Peasants are smuggling their products across the border to neighboring countries for better prices. Chiluba has relied on the security forces to put down peaceful demonstrations and some Zambians have been shot or killed by the police. To say the least, Chiluba has lost the support of his own constituency and moving the democratic project to the stage

46. See ibid and "A Radical Program of Action for UNIP" (Alias the "Zero Option) National Mirror, Lusaka, March 15-21, 1993.

47

NYAKUTEMBA ELIAS, "Chiluba's Challenge," op. cit. 
of consolidation is currently not on the agenda, it will take rather enormous efforts to sustain the liberal content and context of current initiatives in the country: "Chiluba will be hard put to convince voters that he can deliver the fruits of democracy in his second term of office, as he failed in the first ${ }^{48}$."

\section{Conclusion}

The Zambian case demonstrates the limitations of liberal democracy in economies in deep crisis. Democracy has not reduced corruption and the abuse of office. True, it has opened up the political landscape, but it has not wiped out human rights abuses, reduced primordial conflicts, promoted accountability, or reduced poverty in any way. In fact, in spite of pluralism, unemployment, poverty, crime, prostitution, violence, and general social decay have increased. As well, in spite of the initial enthusiasm about Zambian democracy and promises of foreign aid, these have not materialized and investors are not rushing to invest in the country especially as its socio-economic crisis continue to deepen. The MMD is certainly a conservative political movement which is committed to orthodox adjustment programs. Yet, the failure of the same adjustment program had delegitimized the Kaunda government and culminated in its massive defeat in the 1991 election. How the MMD hopes to carry on with the policy, without guaranteed foreign support, diversification of its economy, better copper prices, and some appreciable degree of debt-relief is a challenge.

In terms of power relations, regional conflicts, primordial considerations, and accountability, the MMD has not differentiated itself from the previous Kaunda government in a substantial way. In several respects, it is much worse than the Kaunda government. This is largely because virtually all the leaders and initial ministers of the MMD were former Kaunda ministers who had been sacked for corruption, incompetence, and

48

ibid. 
abuse of office. They had joined in setting up the MMD to challenge Kaunda not because they believed in democracy, but because they wanted to re-enter Zambian politics and have direct access to the state and its resources. The lack of democracy in the numerous opposition parties and their weak and confused programs and patterns of politics, reveals much about the caliber of the founders and ministers who had run the MMD. What lessons do we draw from the Zambian experience therefore?

The first lesson is that democratization or at least a transition to democracy is possible without the prerequisites established in the literature: economic development, a large urbanbased working class, a productive bourgeois class, a culture of conflict resolution and negotiations between elites, and a conducive international environment ${ }^{49}$. In reality, those prerequisites are the goals for which people struggle and might as well be treated as the outcomes of democracy as Terry Lynn Karl has also argued ${ }^{50}$. Second, there is a need to be more nuanced about the nature, politics, composition, and goals of the prodemocracy movements and new political parties in Africa. Many are more conservative than incumbent regimes. They are also dominated by disgraced, corrupt, opportunistic, and "emergency" or "born again democrats. Women as still marginalized, they remain urban-based, excessively personalize their politics, and seek legitimization of the political credentials from outside interests rather than from local communities and constituencies. Such politicians and movements are likely to be obstacles to democratic consolidation. In Zambia, the likes of

49 . For a discussion see ALMOND G.A., The Civic Culture, Princeton: Princeton University Press, 1963; HUNTINGTON SAMUEL, The Third Wave, op. cit, LIPSET S.M., "Some Social Requisites for Democracy: Economic Development and Political Lcgitimacy, "American Political Science Review Vol. 53, (1), 1976; and MOORE BARRINGTON, Jr., The Social Origins of Dictatorship and Democracy; London: Allen Lane, 1967)

50. KARL TERRY LYNN, "Dilemmas of Democratization in Latin America," Comparative Politics (2), October 1990, pp. 1-21. See also LEMARCHAND RENE, "African Transitions to Democracy: An Interim (and Mostly Pessimistic) Assessment," Africa Insight Vol. 22, (3),1992, pp. 178-185. 
Vernon Mwaanga have done so much damage to the process of democratic consolidation, and have created serious doubts in the minds of the people about the sincerity of the prodemocracy movements, third wave political parties, and their leaders. Third, in an economy in deep crisis like Zambia, even good intentions and donor support might not be enough to sustain democracy. It would require very drastic structural transformations for foreign aid to make any impact. Chiluba did not alter the structure and nature of public institutions. Many of the symbols, institutions, and legacies of the previous regimes were retained. These have worked steadily to contain the enthusiasm for multiparty democracy, subverted reform programs, and provided platforms for the opposition to regroup to challenge the government. Fourth, the masses of the people have a very limited elasticity of pain. Just emerging from authoritarian repression and manipulation, and haven been fed on promises of a better future, they expect immediate results. It means that third wave parties and popular movements must do their research, articulate a viable platform, understand the terrain of politics, and tell the truth to the electorate. The excuse of the devastation precipitated by previous governments can only be used, at the maximum, for one year. When the people fail to see results, and when, as in the case of Zambia, they see increasing corruption and mismanagement, they transfer their loyalties to other constituencies and the opposition. Fifth, continuing ethnic, regional, and religious divisions remain a challenge to democracy and development. So far, the new movements have focused on the failings of incumbent regimes in economic matters. There is need to map out a clear agenda for containing divisions along primordial lines as well as issues of gender equality, environmental protection, and human rights. The MMD does not have such a program. Denying the existence of nepotism and ethnic manipulation does not resolve the problem. Zambians generally think that the MMD is Bemba-dominated. So far, the government has not developed a viable agenda for transcending the negative impact and implications of ethnic loyalty. Sixth, we see from Zambia, the fact that democracy does not bring development, at least, the connection is not automatic. The possibilities are there but the contradictions and constraints 
are equally legion. Commitment to an orthodox adjustment program which continues to victimize the already vulnerable majority without safety nets, will mediate rather than promote democracy. Unless the transition process involves the generation of new ideas, alternative pro-people reform programs, mobilization of people across ethnic and other lines, and the promotion of a new work culture, accountability, accommodation, and a new commitment to productivity, liberal democracy will make little or no difference. Finally, and this is probably the most important issue: It is doubtful if a new democratic government can use the same state structure which had been employed by an earlier government to intimidate, exploit, and repress the people for genuinely alternative programs. The MMD has not tried to dismantle and restructure the repressive Zambian state. Rather, it has tried to accommodate the same elites, institutions, constituencies, and interests which aided Kaunda in running down the economy and squandering possibilities for growth, development, and democracy. Democracy, in this context, will end up, like Mike Mpokoda, a laid off worker at Kabwe Mines put it, "like a trick ${ }^{51}$."

Austin december 1995

51. RICHBURG KEITH, "For Many Zambians, Democracy is a Dirty Word," op. cit. 